\title{
Obituaries
}

\section{MALCOLM N. (TONY) NAYLOR RD}

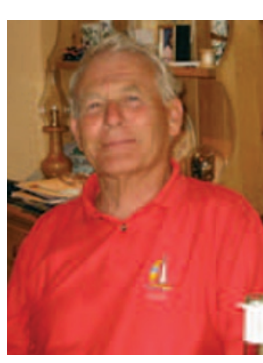

Professor Malcolm N. (Tony) Naylor $\mathrm{RD}$, who died on 15 April 2008, made a major contribution to the specialty of periodontology and to preventive dentistry in the

UK throughout his professional life. In addition he was involved with a range of public, professional, educational and military bodies.

Born in 1926, Tony served on HMS Suffolk during the Second World War and then studied dentistry at Birmingham. After completing 2nd BDS, Tony was awarded a Nuffield Scholarship for two years to obtain an intercalated Honours BSc in Physiology. This was followed by junior appointments at Birmingham and Dundee, and in 1959, Tony was appointed to the Dental Research Fellowship at Guy's Hospital Dental School, where he would be based for the rest of his professional life. He gained his FDS and was later awarded an Honorary FDS from the Royal College of Physicians and Surgeons of Glasgow. He was awarded his PhD in 1962 for his thesis 'A Study of the Sensory Mechanisms in Human Teeth'. Tony became a Senior Lecturer and Reader before being awarded a Chair in 1970. As a clinician he specialised in periodontology but most of his subsequent research was associated with effects of fluoride on tooth decay prevalence and its metabolic pathways. Tony was appointed as an Honorary Consultant in 1966 and was Head of the Department of Periodontology and Preventive Dentistry from 1980 until his retirement in 1991.
Thereafter he was an Honorary Senior Research Fellow at the Eastman. He remained a civil consultant dental surgeon to the Royal Navy until retirement, and was appointed the Queen's honorary dental surgeon.

Tony was involved in the education of generations of dentists and periodontists from Guy's and UMDS, at both undergraduate and postgraduate level, and wrote a history of the Guy's Dental School to celebrate its centenary in 1998. He was president of the BSDR from 1990 to 1992 and President of the Section of Odontology of the Royal Society of Medicine in 1984 and 1985. He was a long term scientific advisor and scientific editor for the $B D J$ (over 30 years) and after retirement chaired the Oral $\mathrm{Ct}$ Dental Research Trust.

Beyond dentistry, Tony was admitted as a Freeman of the City of London, and a liveryman of the Worshipful Company of Bakers, in 1981. He was involved at governor and trustee level with several schools and colleges in and around London.

His associations with the Navy and Sea Cadets (as a Council member until 1994) continued, and he spent time on his boat to the end of his life. His firm religious beliefs helped him cope with the loss of his wife Mary in 2006, and he continued as a lay reader, and was proud of his son, Andrew, and his work as a general practitioner. Even in retirement, Tony was continually active, mixing ongoing professional interests with other aspects of his life, and continued to actively challenge dental research findings submitted by industry to support advertising of new products. He will be greatly missed by so many, both within and outside the profession, who were touched by his work and support.

M. Ide, R. Palmer, S. Challacombe King's College London Dental Institute

Tony Naylor was always mindful that the editors and scientific advisors of the $B D J$ were the temporary custodians of its long history as the scientific publication of the BDA. In his role as scientific assistant editor for 19 years, he was meticulous in attention to detail, whether in correcting proofs or undertaking the scrutiny of papers submitted for publication, which secured the scientific reputation of the British Dental Journal, nationally and internationally. His Journal colleagues shared Tony's pride when his outstanding commitment to the $B D J$ for over 30 years was recognised by the Association in 1987 with the award of the prestigious Tomes Medal.

When, as a fledgling editor, I had the audacity to attempt to modernise the $B D J$ there was some strong opposition from within 'the ranks'. Tony with his own endearing brand of cheerful enthusiasm and willingness to embrace change gave me unfailing encouragement and loyalty, which ensured that the $B D J$ did march into the twenty-first century and for his contribution to that advance we should all be grateful.

Dame Margaret Seward BDJ Editor 1978-1992 